\title{
Assessing the Efficacy of Business Ethics Instruction on Business Students' Cognitive Moral Development in Faith-Based Institutions of Higher Learning in Tanzania
}

\author{
Eusebius S. Kyando \\ Graduate Business School \\ The Catholic University of Eastern Africa \\ Nairobi-Kenya \\ Dr. Joseph Okumu \\ Centre for Social Justice and Ethics \\ The Catholic University of Eastern Africa \\ Nairobi-Kenya \\ Dr. Abraham Kiflemariam \\ School of Business \\ The Catholic University of Eastern Africa \\ Nairobi-Kenya
}

\begin{abstract}
The current study investigated the efficacy of business ethics instruction on business students' Cognitive Moral Development (CMD) in faith-based institutions of higher learning in Tanzania. The study employed demographic characteristics namely, age and work experience as moderating variables. The researchers collected responses from 304 business students. The study used a quantitative research design in order to critically analyse data. They tested two hypotheses. First, that business ethics instruction does not improve business students' CMD. Second, that age and working experience do not influence students' CMD. The results from the analyses revealed that business ethics instruction influences students' CMD. Age and work experience explained much of the variability of the influence. The results confirmed Kohlberg's theory that as persons mature they move to the higher level of moral development. The present study recommends for future research, among others, to study on the relationship between business students' $C M D$ and their ethical behaviour.
\end{abstract}

Key words: Business Ethics, Business Ethics Instruction, Cognitive Moral Development

\section{Introduction}

Considering unethical practices facing many organizations especially those in developing countries, it has become essential for institutions of higher learning to focus on business ethics training. This will help to prepare future business and financial managers with the ability to handle ethical dilemmas that occur frequently in businesses. As such, the efficacy of business ethics instruction towards CMD cannot be underestimated. CMD comprises elements such as ethical reasoning (ER), ethical perception (EP), and ethical decision-making (EDM).

Thus, increasing academic interest in business ethics has been partly brought about by unprecedented corporate scandals and partly by other forms of non-compliance to the fundamental principles of professional ethics in the corporate workplace by individuals (Micewsky \& Troy, 2006; Smyth, Davis, \& Kroncke, 2009; Jorge \& Peña, 2014). The non-compliance with fundamental principles of professional ethics is purported to have led to the global financial crisis in 2007/2008 (Crotty, 2009). Furthermore, the fall of some large companies such as Enron, Tyco, WorldCom, Global Crossing, Qwest, and Health South (Desplaces, Melchar, Beauvais, \& Bosco, 2007; Adkins \& Radtke, 2004) was attributed to a lack of adherence to professional corporate ethics.

The aforementioned occurrences confirmed the statement of Burton and Goldsby (2009: 1) that "good ethics is good business and bad ethics is bad business." The fall of these big companies caused the public to question on the sufficiency of regulatory or legislative actions in providing means to ensure that financial executives demonstrate the capacity in ethical decision-making (Smyth et al., 2009).

The unethical practices have also been of heightened concern within the higher education circles (Nwizu, 2018). 
For example, increasing cases of examination misconduct, sale and purchase of grades, manipulation of grades by officers in the record units, grade-for-sex (sex-for-grade), leakage of examination questions, plagiarism including the publication of the results of students' research work without acknowledging such students, receiving salaries without work, ghost employees, unethical consideration in the recruitment, promotion, and appointment of lectures/staff (Enudu, 2018).

Business ethics therefore, has become not as one additional subject or course that business students take, but rather as a lens through which the whole business curricula is conceived and implemented (Abend, 2013). Students learning how to recognise ethical issues in business, is an important step in evaluating ethical decisions in business. Theodore Roosevelt ${ }^{1}$ corroborated the significance of business ethics instruction and said, "To educate a man in mind and not in morals is to educate a menace to society" (Kidwell, Fisher, Braun, \& Swanson, 2013: 3).

\section{Statement of the Problem}

Corporate scandals have made the news in the last decade or so because have led to the collapse of large companies across the globe (Smyth et al., 2009; Ferrell, Fedrick \& Ferrell, 2015). In Tanzania, the corporate scandals of Richmond, Tegeta Escrow Account, and EPA Scandals have led to more questions on the sufficiency of regulatory systems (Fouere, 2018). As a result, the public has turned its attention to the role of business ethics not only in corporate entities, but also in educating future business executives (Singh \& Stuckelberger, 2017).

Some faith-based institutions of higher learning such as Catholic Universities in Tanzania have made business ethics education mandatory. Despite that, there is little evidence to prove positive correlation between business ethics instruction and students' CMD. Thus, there remains a gap between the two. Moreover, the available literature on the correlation between them is generic, or altogether lacking, in the case of Tanzania. Therefore, this study sought to establish (whether there is) a positive correlation between business ethics instruction and learners' CMD.

Although there are some general literatures on ethical issues in business, business ethics prediction on CMD as an academic field and as an area of research has received little attention. In particular, few empirical studies have been carried out in the aforementioned field in the region particularly in Tanzania. Although apparently business course is delivered in many faith-based institutions in Tanzania, the result on whether it affects learners' CMD is lacking.

\section{Hypotheses of the Study}

The present study was guided by the following two null hypotheses:

$\mathrm{H}_{0} 1$ : Business ethics instruction does not improve students' CMD

$\mathrm{H}_{0}$ 2: Age and work experience do not influence students' CMD

\section{Literature Review}

\section{Theoretical Review}

The present study was anchored on the Cognitive Moral Development theory which was advanced by Lawrence Kohlberg based on Piaget's work on moral development in children. Kohlberg's theory claims that ethics instruction determines learners' ability to respond to ethical issues in business.

The theory has been used in examining the levels of moral reasoning of business students after taking business ethics course (Jones, Massey, \& Thorne, 2003). Other studies used the theory for the evaluation of business ethics training (Gahir, 2007; Prehn et al., 2015) and assessment of a relationship between moral cognitive development and the level of instruction (Nather, 2013).

The current study has applied Kohlberg's theory in order to determine the correlation between business ethics instruction and learners' CMD. The theory is useful for this study because of its assumption that individuals after attending an ethics instruction will respond to ethical issues in business through a cognitive moral process based on the levels of moral development as shown in the figure below.

\footnotetext{
${ }^{1}$ The $26^{\text {th }}$ President of the United States of America
} 
Figure 1. Kohlberg's Stages of Moral Development

\begin{tabular}{|l|l|l|}
\hline Level & Stage & Characteristics of a stage/level \\
\hline $\begin{array}{l}\text { Post- } \\
\text { Conventional }\end{array}$ & 6 & $\begin{array}{l}\text { The right behaviour means acting according to an individual's own ethical } \\
\text { principles; in other words, unwritten global deontological ethical principles of } \\
\text { justice, duty, and equal human rights are followed at this stage. }\end{array}$ \\
\cline { 2 - 3 } & 5 & $\begin{array}{l}\text { The correct behaviour is a combination of individuals rights and principles } \\
\text { agreed upon by society. }\end{array}$ \\
\hline Conventional & 4 & $\begin{array}{l}\text { In this stage one experiences a sense of fairness, mutual loyalty and dedication } \\
\text { where the individual develops an ability to adhere to legal and moral codes. }\end{array}$ \\
\cline { 2 - 3 } & 3 & Individual is concerned with maintaining interpersonal relationships. \\
\hline Pre-conventional & 2 & Individual behaves morally to gain personal rewards. \\
\cline { 2 - 3 } & 1 & Individual obeys the rules to avoid punishment. \\
\hline
\end{tabular}

\section{Adapted from Kohlberg (1984)}

As indicated earlier, the theory has been used extensively in many studies to determine the levels of ethical reasoning abilities, ethical perception, and ethical decision-making of students after ethics instructions (Jones et al., 2003). It has found support among organisational researchers, such as Ferrell and Gresham (1985) who applied it on "Contingency Framework for ethical decision-making in organisations".

Authors such as Jones et al. (2003) utilised the theory in examining the levels of moral reasoning abilities of business students and professionals after taking business ethics course. Their examination revealed that the course improved the level of reasoning of students under the study. Similarly, Wells and Schminke (2001) and Weber (2007) recommend the use of CMD theory in case studies.

Kohlberg's theory is in line with the business ethics instruction's goal of assisting students' process of growth from one moral cognitive stage to another. Waples et al. (2009) also recommend that those who use it as the foundation for business ethics instruction on business students may do it successfully. The Defining Issues Test (DIT) was also based on Kohlberg's Theory as it was used to assess differences in students' moral development after exposure to business ethics education (Rest, 1994; McNeel, 1994; Bigel, 2002; and Waples, Antes, Murphy, and Munford 2009).

\section{Empirical Review}

Several empirical studies have been carried out on business ethics instruction and their results show that the instruction improves business students' CMD which is measured via ethical reasoning, ethical perception, and ethical decisionmaking (Lau, 2010; Canarutto, Smith, K.T. \& Smith, L.M., 2010; Murphy, 2011; Stachowicz-Stanusch, 2011; Valentine \& Bateman, 2011; Queensberry, Phillips, Woodbourne \& Yang, 2012; Jazani and Ayoobzadeh, 2012; Saat, Porter, \& Woodbine, 2012; May, Luth, \& Schwoerer, 2014; Cameron \& O'Leary, Reynolds, \& Dang, 2015; Akrivou, \& Bradbury-Hang, 2015; Singh \& Stuckelberger, 2017; Ike \& Onyia, 2018; Ahmed, Chung, \& Eichenseher, 2003; Atakan, Bumaz, \& Topcu, 2008; Symth et al., 2009; Eweje \& Brunton, 2010; Khalizani, Omar, and Khalisanni, 2011; Uyar \& Gungormus, 2013; Lumsden \& Fatoki, 2013; Jorge \& Peña, 2014; Nguyen \& Phan, 2015).

A study by Weber and Glyptis (2000) found that ethics education had a positive influence on students' values and opinions. Another more comprehensive study was done by Lau (2010) found that ethics education significantly improved students overall ethical orientation and seemed to give them a higher ethical awareness. The study indicated also that students who completed the course of business ethics scored higher on ethical stance on a range of ethical issues in business than those who had not completed the course.

A further study was done by Cloninger and Selvarajan (2010) had similar results as it indicated that business ethics courses were successful and students demonstrated better ethical judgements after the course. The same results were arrived at by Nguyen et al (2008) who stressed in their study's conclusion that a business ethics course must be designed and developed properly in order to bear the desired results. Bloodgood, Turnley, and Mudwick (2008) found that business ethics instruction has the potential in making people less likely unethical because of its various forms of training and interventions which increase moral reasoning for some individuals.

Waples et al. (2009) did a meta-analytic investigation of business ethics instruction of 25 previously conducted business ethics instructional programs. Their overall results indicated that business ethics instructional programs lead to 
minimal improvement of business students' CMD as measured by ethical perception, ethical awareness, and ethical behaviour scores. Other factors include study characteristics of participants such as age, gender, and work experience. This view was also pointed out earlier by Glenn (1992) who insisted on the instrumentation involved in business ethics instruction.

The concern for the improvement of business students' CMD after business ethics instruction is upheld also by Deplaces et al. (2007) on their study on the impact of business instruction on moral judgement competence of business students. The results of their empirical study indicated the need for further examination of the connections among academic structures, ethical pedagogy, and students' cognitive moral development.

A similar study on business ethics instruction was done later by May et al. (2014). The study used a quasi-experimental pre-test-post-test research design. Their findings revealed that business ethics instruction improves business students' abilities to handle ethical problems at work (moral efficacy), boost the relative importance of business ethics in their work lives (moral meaningfulness), and encourage them to be more ready to raise ethical issues at work (moral courage).

The three variables namely, moral efficacy, moral meaningfulness, and moral courage as used by May et al. (2014), summarise what Waples et al. (2009) call the goals or criteria types of business ethics instruction which include ethical awareness, ethical perception, ethical decision-making, ethical reasoning, and ethical behaviour. Other authors like Lau (2010) call these goals as constructs. The current study employed ethical reasoning, ethical perception, and ethical decision-making as elements of CMD.

\section{The Influence of Age and Work Experience on CMD}

Following an old adage that old age brings wisdom, many studies have investigated how business ethics instruction improves business students' CMD according to age (Alleyne, Devonish, Allman, Charles-Soverall, \& Marshall 2010; Cloninger \& Selvarajan, 2010; Elias, 2011; Mack, 2010; Nather, 2013). According to Akman (2011); and Eweje and Brunton (2010), age is another moderating variable that influence business students' CMD. This study is consistent with Kohlberg's (1984) identification of age as a determinant of ethical behaviour which is also supported by later studies done by Hunt (1986); Rest (1986); Ferrel et al. (2003); and Adkins and Radtke (2004).

Nather (2013) examined the factors that might impact the development of moral judgement and found that age was associated with the stage of moral reasoning, although the best correlate was the level of schooling. On the other hand, a study done by Khalizani (2011) in Malaysia showed opposite results. Khalizani found that age and other determinants of effective business ethics instruction such as academic exposure, ethnicity and culture do not have a significant relationship with ethics perceptions of students.

A similar study but a meta-analytic analysis done by Waples at el. (2009) also found that age does not have substantive influence on decision-making among business students. However, they concluded that some training efforts which include moral reasoning, may lead to differences in the level of improvement of business students' CMD according to student's age.

Many of the empirical studies have shown that age influences business students' CMD. This is in accordance with researches which show that our choices we make in situations with ethical contents are influenced by our maturity level (Rest, 1986; and Ferrell et al., 2003). This is in line with Kohlberg's identification of age as determinant of ethical behaviour.

Work experience is a new parameter in the field of business ethics (Eweje and Brunton, 2010). Weeks, Moore, McKinney, and Longenecker (1999) take work experience to be synonymous with a career stage which include exploration, establishment, maintenance, and disengagement stages. According to Cron (1984) and Weeks et al., a career stage might affect a person's attitudes towards ethical issues depending on the stage.

Exploration and establishment stages are prone to ethical issues compromise. In the exploration stage, the superior may demand a certain standard of performance from the subordinate who in return may be tempted to compromise ethical issues in order to achieve the demanded level of performance (Eweje \& Brunton, 2010). On the other hand, in the maintenance stage the employee has already enjoyed self esteem from the past achievements and hence, does not need to prove oneself by compromising ethical issues.

A study was done by Eweje and Brunton (2010) on the impact of work experience and other parameters such as gender and age on students' ethical perception. Their results indicated that older students with work experience appeared to show more ethical awareness than younger students in general. Students with work experience when are taught about 
ethical issues in business tend to reflect on their own experiences in work environment (AACSB International, 2004). This conclusion confirms Kohlberg's theory which holds that ethical awareness of people at later stages of moral development is better than that of those at earlier stages (Velasquez, 2012).

However, Khalizani et al. (2011) found that there is no relationship between business ethics instruction and business students' work experience or what they called as business exposure. A similar study with inconsistent results was done by Adkins and Radtke (2004). The study revealed interesting results as the business students seemed to consider business ethics instruction to be important while faculty members consider not important. One would expect that members of the staff of business studies would have a more positive attitude towards business ethics than their students because of their work experience. However, these results show that work experience does not have an impact on attitude towards business ethics.

As already indicated, work experience is a new parameter in business ethics and hence it has scant resources. This is an indication that the area needs more exploration by researchers especially in business schools which comprise students with and without work experience. This study therefore, sought to determine the extent to which students' CMD improvement differs according to work experience.

\section{Knowledge Gaps}

The theoretical and empirical literature reviewed underscores the link between business ethics instruction in institutions of higher learning and students' CMD. The literature reviewed showed contextual, methodological, and relevance gaps. This section aimed at addressing the aforementioned gaps.

First, there is little written evidence on the efficacy of business ethics instruction on students' CMD in institutions of higher learning in Africa South of the Sahara and Tanzania in particular, with the exception of South Africa. Many of the studies done on business ethics instruction are found mostly in Europe, Asia, and the USA. This is a contextual business ethics literature gap. Even Mawa and Adams (2015) report that although there exists in East Africa some general literature on ethical issues of business, business ethics as academic field has received little attention as an area of research.

Second, the available business ethics literature in Africa South of the Sahara is scant and obsolete. For instance, Global Survey of Business Ethics (Global Ethics No. 5) in training, teaching and research commissioned by global ethics.net 2012 in Geneva, provides a report of a survey done in East Africa relying on the works of Rossouw and Stuckelberger (2000).

The available information is old and almost obsolete because changes have taken place since then including the establishment of new universities which also have business ethics in their business curricula. This shows that the available business ethics literature renders a relevance gap. These universities include the Catholic University of Eastern Africa and Strathmore University in Kenya; St Augustine University of Tanzania, Mwenge Catholic Universality and Jordan University College both in Tanzania. The report itself holds that business ethics is taken in the region as an academic field rather than as an area of research.

Third, several studies have been carried out to suggest that ethics can be taught and that ethics instruction contributes to the improvement of ethical behaviour among business students. Such studies include, among others, Warren, Gaspar, and Laufer (2014) ); Rittter (2006); Rossouw (2002); and Eweje and Brunton (2010). These empirical studies revealed that apart from influencing students' ethical awareness and decision-making, business ethics instruction also impacts students' ethical behaviour. In addition, Hooker (2003); Jones et al. (2015); and Akrivou and Bradbury-Hang (2015) point out that ethics courses have a number of features that are likely to impact behaviour.

These studies employed tools such as DIT and ATBEQ which are used to measure students' improvements in ethical perception, ethical reasoning, and ethical awareness, to measure students' ethical behaviour. This is a methodological research gap because evidence from participants' self-reports is not a strong evidence of participants' actual behaviour.

Rest (1986) also argues that there is no clear existence of linear relationship between moral reasoning and actual moral behaviour. Lind (2008) argues that it is not easy to measure the moral behaviour because our observations can be easily misled when we are too quick in making judgement about someone's morality. This is a methodological gap that needs to be addressed in the future studies on business ethics.

In order to study the actual ethical behaviour of learners, a research needs a methodology that employs close examination of participants such as ethnography. Ethnography is the in-depth study of a culture or a facet of culture. It is a descriptive study of a particular human society by basing entirely on fieldwork and requires the complete 
immersion of the researcher in the everyday life of the subjects of the study. Therefore, simple responses from the questionnaire by participants cannot necessarily guarantee the expression of their ethical behaviour.

\section{Methodology}

The present study employed a post-positivism research paradigm because it combines both numeric measures and concepts and constructs of social realities. CMD is a social reality which advocates for post-positivism approach. CMD included social constructs namely, ethical reasoning, ethical perception, and ethical decision-making. In many respects post-positivism research philosophy attempts to employ the same research principles and procedures as those used by social sciences to reach conclusion (McMurray, 2009). Therefore, this study attempted to measure ethical perception, ethical reasoning, and ethical decision-making by assigning scores from the responses of the research subjects in order to determine whether business ethics instruction improves students' CMD. In this regard, these social constructs were quantified for measurability purpose to meet the post-positivist research philosophy.

The present study employed a quasi-experimental research design involving a treatment group of business students who had done a business ethics course and a non-treatment group of business students who had not yet done a course of business ethics in order to determine whether business ethics instruction improves students' CMD or not. Quasiexperimental design is normally used to compare treatment and non-treatment groups in research (Reichardt, 2009).

According to Baruch and Holtom (2008), the majority of empirical studies conducted within managerial and behavioural sciences use questionnaire as the data collection tool because it provides insight into individual perception and attitudes. Therefore, the current study employed a quantitative research design whereby students' responses to questions on ethical reasoning, ethical perception, and ethical decision-making were gathered and measured as part of the explanatory process.

The target population for this study was all students majoring in business studies from faith-based institutions of higher learning in Tanzania. According to Albaum and Peterson (2006), many empirical studies on business ethics issues have been using business students' samples. The population of the study was heterogeneous as it included male and female, from different religious status, different ages, working experiences, and different institutions. During data collection carried out from July to October 2019, the target population was 1272. This total was obtained from offices of deans, heads of departments and corporate councils from faith-based institutions of higher learning in Tanzania.

The sample size from business students was determined using Yamane (1967) sample size determination formula. Yamane's formula has been used extensively in the determination of a sample size. It is appropriate for a simple random sampling technique (Bulletin of the Gauhati University Mathematics Association, 2012). According to Yamane, for a $95 \%$ confidence level and $\mathrm{p}=0.05$, size of the sample should be:

$n=\frac{N}{1+N(e)^{2}}$

Where:

$\mathrm{n}=$ the desired sample size; $\mathrm{N}=$ the target population; $\mathrm{e}=$ Confidence level $(0.05)$

$\mathrm{N}=1272 ; \mathrm{e}=0.05$. Therefore, $\mathrm{n}=1272 / 1+1272(0.05)^{2}=304$

The sample size of 304 business students was divided into two groups. The first group included 152 business students from the faith-based institutions of higher learning who had done business ethics as a treatment group. The second group included 152 business students from the faith-based institutions of higher learning who did not do business ethics. This group formed the non-treatment group. The questionnaires were given randomly to business students who received business ethics instruction as well as those who did not have business ethics instruction. The two groups were from different faith-based institutions of higher learning. Therefore, the total sample size for the study was 304 business students from faith-based institutions of higher learning in Tanzania.

\section{Empirical Findings and Discussions}

\section{Business Ethics Instruction and Students' CMD}

In order to determine if business ethics instruction improves business students' CMD, the researchers compared the mean scores of business students comprising those who had done business ethics and those who did not. Those who did business ethics formed a treatment group and those who did not comprised of a non-treatment group. 
This procedure was used also by May et al. (2013) who investigated whether a graduate-level course in business ethics could influence students' confidence in their abilities to handle ethical problems at work (i.e. moral efficacy), boost the relative importance of ethics in their work (i.e. moral meaningfulness), and encourage them to be more courageous in raising ethical problems (i.e. moral courage). May et al. categorised students into treatment and control groups and tested for the sample means difference.

Lau (2010) also investigated the relationship between ethics education and students' ethical reasoning and awareness by separating the sample of business undergraduate students into treatment and control groups. The control group consisted of students who enrolled in a required organisational behaviour class and who had not taken an ethics class. The treatment group consisted of students enrolled in a required ethics class.

Guerrero (2010) investigated the importance of a special training of Call Centres' employees. Guerrero compared the samples mean scores of the employees with standard training and those with special training using the z-Test: Two Samples Means. The z-Test: Two Samples Means. However, the z-Test: Two Samples Means requires that the standard deviation of the population should be known exactly (Gaur \& Gaur, 2009). In real life, it is not possible to calculate the exact standard deviation for populations especially for the large ones. For this reason, t-Test: Two-Sample Assuming Unequal Variances was employed. Izzo (2000) also compared the treatment and control group pairs by calculating the significance of the difference in their respective mean post-test scores on the dependent variables.

After categorising the responses into treatment and non-treatment groups, the researcher proceeded with the analysis for each element of CMD namely, ethical reasoning, ethical perception, and ethical decision-making by using the tTest: Two-Sample Assuming Unequal Variances with the purpose of testing the null hypotheses one, two, and three.

The t-Test: Two-Sample Assuming Unequal Variances outcome for all elements of CMD showed that the test statistics $\mathrm{t}$ were greater than the critical two-tail values. The t-Test: Two-Sample Assuming Unequal Variances results showed also that the p-values two-tail were miniscule, and far smaller than the 0.05 level which was set for the alpha.

The difference in the mean scores between the treatment and the non-treatment groups was significant. Therefore, the null hypothesis that business ethics instruction does not improve business students' ethical reasoning, ethical perception, and ethical decision-making was rejected in favour of the alternative hypothesis that business ethics instruction improves learners' ethical reasoning, ethical perception, and ethical decision-making. The results were summarised in the following diagram.

Table 1 Summary of the Impact of Business Ethics Instruction on Learners' CMD

\begin{tabular}{|l|l|l|l|l|l|l|}
\hline CMD & $\begin{array}{l}\text { TREATMENT } \\
\text { GROUP } \\
\text { MEAN SCORES }\end{array}$ & $\begin{array}{l}\text { NON-TREATMENT } \\
\text { GROUP } \\
\text { MEAN SCORES }\end{array}$ & $\begin{array}{l}\mathbf{t} \\
\text { Stat }\end{array}$ & $\begin{array}{l}\mathbf{t} \text { Critical two } \\
\text { tail }\end{array}$ & $\begin{array}{l}\text { P(T<=t) two- } \\
\text { tail }\end{array}$ & $\begin{array}{l}\text { HYPOTHESIS } \\
\text { STATUS }\end{array}$ \\
\hline ER & 32 & 26 & 9.89 & 1.96 & $1.24422 \mathrm{E}-19$ & REJECTED \\
\hline EP & 32 & 21 & 21.08 & 1.96 & $4.28411 \mathrm{E}-61$ & REJECTED \\
\hline EDM & 31 & 27 & 4.75 & 1.96 & $3.36177 \mathrm{E}-06$ & REJECTED \\
\hline
\end{tabular}

\section{Selected p-value is $5 \%$}

From the table above, all the p-values obtained were less than the specified alpha value (0.05). The null hypothesis that business ethics does not improve business students' CMD was rejected in favour of an alternative hypothesis that business ethics instruction improves students' ethical reasoning, ethical perception, and ethical decision-making (CMD). The results concurred with the studies done previously on business ethics instruction and the improvement of students' CMD such as, the meta-analytic study by Waples et al. (2009); Desplaces et al. (2007); Eweje and Brunton (2010). Other empirical studies with similar results include Klugman and Stump (2006); Caliyurt (2007); Lau (2010); Canarutto, Smith, K.T. and Smith, L.M. (2010); Murphy (2011); Stachowicz-Stanusch (2011); Valentine and Bateman (2011); Queensberry, Phillips, Woodbourne and Yang (2012); Jazani and Ayoobzadeh (2012); Saat, Porter, and Woodbine (2012); Cameron and O’Leary, Reynolds, and Dang (2015); Akrivou, and Bradbury-Hang (2015); Singh and Stuckelberger (2017).

Another study was done by Desplaces et al. (2007) on moral judgement competence of business students after faculty members and business students engaged into discussion of business ethics during business courses. Desplaces et al. define moral judgement competence as the ability to make decisions that are moral. The results of their study indicated that students' moral judgement competence (decision-making) improved after such interaction between the staff and students on business ethics. 
The above conclusions confirmed Kohlberg's Cognitive Moral Development Theory that individuals after some ethical instructions will respond to ethical issues according to their respective stages of moral development by applying moral norms they learned and analyse situations of moral consequences. As they progress through what Kohlberg (1984) calls cognitive moral development, learners through business ethics instruction gain more exposure and their ethical reasoning improve.

\section{The Influence of Age and Working Experience on CMD}

A Path Analysis test was carried out to test the null hypothesis that moderating variables, age and work experience do not influence the dependent variables namely, ethical reasoning, ethical perception, and ethical decision-making. The Path Analysis table below provided the results.

\section{Table 2}

\section{Path Analysis for Age: Regression Weights}

\begin{tabular}{|l|l|l|l|l|l|l|l|}
\hline & & & Estimate & S.E. & C.R. & P & Label \\
\hline $\begin{array}{l}\text { GRANDTOTAL } \\
\text { ER }\end{array}$ & $<---$ & AGE & .872 & .156 & 5.588 & $* * *$ & par_1 \\
\hline $\begin{array}{l}\text { GRANDTOTAL } \\
\text { EP }\end{array}$ & $<---$ & AGE & .744 & .154 & 4.835 & $* * *$ & par_2 \\
\hline $\begin{array}{l}\text { GRANDTOTAL } \\
\text { EDM }\end{array}$ & $<---$ & AGE & .508 & .163 & 3.124 & .002 & par_3 \\
\hline
\end{tabular}

The Path Analysis output had p-values below the threshold of 0.05 for all elements of CMD. The results revealed that age influences students' CMD. Therefore, the null hypothesis that age does not influence students' CMD was rejected. This was shown also by the strength of the association of age towards ethical reasoning, ethical perception, and ethical decision-making in the following Path Diagram.

\section{Figure 2}

\section{Path Diagram Age}

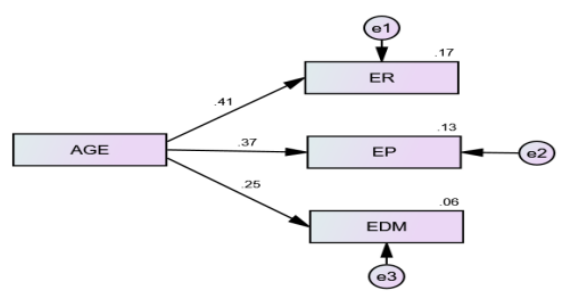

The Path Diagram indicated that the strength of the association between age and CMD elements was strong. The rule of thumb in the SEM is that correlation values with coefficient $r$ less than 0.10 do not explain the corresponding correlations very well (Kline, 2011). The contribution of age towards ethical reasoning was $42 \%$, ethical perception was $37 \%$, and ethical decision-making was $25 \%$.

The results are in agreement with previous empirical studies which attempted to investigate how business ethics instruction improves business students' CMD according to age (Alleyne et al., 2010; Cloninger \& Selvarajan, 2010; Elias, 2011; Mack, 2010; Nather, 2013). Akman (2011); and Eweje and Brunton (2010) take age as a moderating variable that influence business students' CMD. In addition, the empirical study done by Eweje and Brunton (2010) indicated that older students appeared to have more ethical awareness than younger students in general.

The results of the present study on age confirmed Kohlberg's (1984) theory which holds that individuals after ethics education will respond to ethical issues according to their respective stages of moral development impacted by personal characteristics such as age. The theory identifies age as determinant of moral development. This assumption is also 
supported by Hunt (1996); Rest (1986); Ferrel et al. (2003); and Adkins and Radtke (2004) who hold that our choices we make in situations with ethical contents are influenced by our maturity level.

As was stated earlier in the current study, work experience is a new parameter in the field of business ethics (Eweje and Brunton, 2010). The present study tested its influence on students' CMD using Path Analysis. A Path Analysis was done and the outputs are provided in the following table.

Table 3

Path Analysis for Work Experience: Regression Weights

\begin{tabular}{|l|c|c|l|l|l|l|l|}
\hline & & & Estimate & S.E. & C.R. & P & Label \\
\hline $\begin{array}{l}\text { GRANDTOTAL } \\
\text { GRANDTOTAL } \\
\text { ER }\end{array}$ & $<---$ & WE & .565 & .143 & 3.945 & $* * *$ & par_1 \\
\hline $\begin{array}{l}\text { GRANDTOTAL } \\
\text { EP }\end{array}$ & $<---$ & WE & .494 & .139 & 3.543 & $* * *$ & par_2 \\
\hline $\begin{array}{l}\text { GRANDTOTAL } \\
\text { EDM }\end{array}$ & $<---$ & WE & .331 & .145 & 2.285 & $\mathbf{. 0 2 2}$ & par_3 \\
\hline
\end{tabular}

The Path Analysis output from the table above showed all pa-values below the threshold of 0.05 which is an indication that work experience can influence ethical reasoning, ethical perception, and ethical decision-making of students. It was also confirmed by the Path Diagram shown in the figure below which revealed the strength of the relationship between work experience and students' CMD.

Figure 3

\section{Path Diagram for the Influence of Work Experience on CMD}

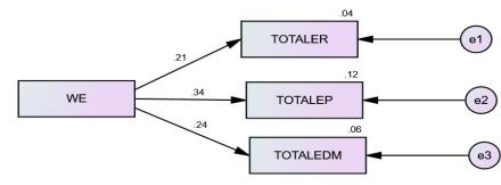

The contribution of work experience towards CMD is significant. It contributed $21 \%$ for ethical reasoning, $34 \%$ for ethical perception, and $24 \%$ for ethical decision-making. The rule of thumb in the SEM is that correlation values with coefficient $r$ less than 0.10 do not explain the corresponding correlations very well (Kline, 2011). These results showed that the relationship between work experience and the elements of CMD is strong. Therefore, the null hypothesis that work experience does not influence students' CMD was rejected.

These results from the tests of DIT scores revealed that work experience influences students' CMD. The results confirmed previous studies on work experience. For instance, a study which was done by Eweje and Brunton (2010) on the impact of work experience on students' ethical perception indicated that older students with work experience appeared to have more ethical awareness than younger students in general.

This was in line with the work done later by Yazici and Siniksaran (2012) who found out that length of work experience matters, suggesting that the higher the years spent in the work environment, the higher the ethical awareness. It is assumed that students with work experience when are taught about ethical issues they tend to reflect on their own experiences in work environment (AACSB International, 2004). Therefore, students with more work experience will portray more ethical attitudes than those who have less. The study done by Rodriguez (2017) revealed a significant difference in the attitude towards business ethics between graduated students with longer work experience and those with less work experience. 
These results give an implication that the graduates become more relaxed in their ethical attitudes during their early years of work experience followed by an increased awareness of business ethics as more years of work experience are accumulated. Rodriguez gives a possible explanation that graduate students enter the workforce with preconceptions of how they should or are expected to maximise shareholders' wealth. Later they get knowledge at the workplace (e.g. ethics violations and their consequences, training, code of ethical conduct) which enhance in them ethical attitudes in business.

\section{Summary of Findings}

The first objective of the current study was to determine whether business ethics instruction improves business students' ethical reasoning, ethical perception, and ethical decision-making. In order to meet this objective, the mean scores of students who did business ethics and those who did not were compared. A z-Test: Two Sample for Means was run for the DIT scores. The results from the tests indicated that business ethics instruction improved business students' ethical reasoning, ethical perception, and ethical decision-making, hence improving students' CMD.

The second objective of the study was to find out whether age and work experience influence business students' ethical reasoning, ethical perception, and ethical decision-making. The results from the Path Analysis indicated that age and work experience explained the variability in business students' ethical reasoning, ethical perception, and ethical decision-making after studying business ethics with the former taking the lead. This showed a clear indication that age and work Experience influence students' CMD.

\section{Conclusion and Recommendations}

This study investigated the relationship between business ethics instruction and business students' CMD in faith based institutions of higher learning in Tanzania. The study specifically sought to find out if business ethics instruction improves business students' ethical reasoning, ethical perception, and ethical decision-making according to age and work experience. This was in relation to the little knowledge available on this matter in Tanzania.

The general conclusion from the present study is that business ethics instruction can improve business students' ethical reasoning, ethical perception, and ethical decision-making. The improvement can differ according to age and work experience of the learners.

The study recommends a sample size which includes also non-faith based institutions of higher learning both private and public in Tanzania for the purpose of fair generalisation of the results. The study also recommends a longitudinal research design in order to measure the impact of business ethics instruction by comparing students' CMD at the beginning and after taking business ethics course (pre and post tests). This approach might add more nuances on the correlation between business ethics instruction and learners' CMD.

As was concluded earlier, business ethics instruction can improve business students' ethical reasoning, ethical perception, and ethical decision-making (CMD). However, it remains unclear whether the improvement in moral cognition means improvement in the ethical behaviour of the students. This renders another opportunity for future research to relate $\mathrm{CMD}$ and ethical behaviour.

\section{Limitations of the Study}

The current study should be considered in the light of several limitations. The purpose of the study was to determine if business ethics instruction improves business students' CMD in faith-based institutions of higher learning in Tanzania.

The first limitation was about the sample size. Although the sample size of 304 was sufficient as per target population of 1272 business students in faith-based institutions of higher learning, it is still small for the generalisation of the results.

The second limitation was to establish the consistency of syllabi across all the faith-based institutions of higher learning in Tanzania. Some institutions might have stand-alone business ethics while others have integrated business ethics into other business courses and others might have both. Even the method of teaching might differ from one institution to the other. Therefore, some variations in the results might have been caused by differences in the content and approach of the business ethics instruction.

The third limitation was that the current study's analysis relied mostly on data collected through questionnaires that were distributed and restricted to student samples. Teachers and business professionals and in-depth interviews if were included would have provided a more realistic representation of business ethics education in the real business world. 


\section{References}

AACSB International (2004). Ethics instruction in business schools: Report of the ethics Instruction Task Force to AACSB International's Board of Directors. AACSB International

Abend, G. (2013). The origin of business ethics in American universities, 1902-1936. Business Ethics Quarterly, Vol. 22, Iss. 2, 171-205

Adkins, N. and Radtke, R.R. (2004). Students' and faculty members' perception of the importance of business ethics and accounting ethics instruction: Is there an expectation gap? Journal of Business Ethics, 51: 279-300

Ahmed, M.M., Chung, K.Y., and Eichenseher, J.W. (2003). Business Students' Perception of Ethics and Moral Judgement: A Cross - Cultural Study. Journal of Business Ethics, Vol.43, 89-102

Akman, V. (2011). Empirical Look at The Factors Affecting Perception of Business Ethics in Turkey. Emerging Markets Journal, Vol. 1. DOI: 10.519emay.2011.5

Akrivou, K., and Bradbury-Hang, H. (2015). Educating Integrated Catalysts: Transforming Business Schools toward Ethics and Sustainability. Journal of Academy of Management Learning and Instruction, vol. 14 (2), 222-240

Albaum, G., and Peterson, R. A. (2006). Ethics attitudes of future business leaders: Do they vary by Gender and Religiosity? Business and Society Journal, 45(3), 300-321, DOI: $\quad 10.1177 / 0007650306289388$

Alleyne, P, Devonish, D., Allman, J., Charles-Soverall, W., \& Marshall, A. Y. (2010).

Measuring Ethical Perceptions and Intentions Among Undergraduate Students in

Barbados. The Journal of American Academy of Business, 1, 5319-5326

Atakan, M.G., Burnaz, S., and Topcu, Y. I. (2008). An Empirical Investigation of the Ethical Perception of Future ManAgers with a Special Emphasis on Gender- Turkish Case. Journal of Business Ethics, 82: 673-586, DOI 10.1007/s10551-007-9577-z

Bloodgood, James M., Tunley, William H., and Mudrack, Peter (October 2008). The Influence of Ethics Instruction, Religiosity, and Intelligence on Cheating Behaviour. Journal of Business Ethics, Vol. 82, No. 3, pp. 558-71.

Caliyurt, K (2007). Accounting Ethics Instruction in Turkish Public Universities. Social Responsibility Journal, Vol. 33, Iss. 4, 74-80

Cameron, R. A., \& O'Leary, C. (2015). Improving Ethical Attitudes or Simply Teaching Ethical Codes? The Reality of Accounting Ethics Instruction. Accounting Instruction Journal, 24,275-290.

Doi:10.1080.09639284.2015.1036893

Canarutto, G., Smith, K. T., \& Smith, L. M. (2010). Impact of an Ethics Presentation Used in the USA and Adapted for Italy. Accounting Instruction, 19, 309. Retrieved from MasterFILE Premier. (Accession No. 35608363)

Cloninger, P. A., \& Selvarajan, T. T. (2010). Can Ethics Instruction Improve Ethical Judgment? An Empirical Study. SAM Advanced ManAgement Journal (07497075), 75(4), 4-49.

Desplaces, D., Melchar, D., Beauvais, L., and Bosco, S. (2007). The Impact of Business Instruction on Moral Judgement Competence: An Empirical Study. Journal of Business Ethics, Vol.74: 73-87.

DOI: $10.1007 / \mathrm{sq} 0551-006-9221-3$

Elias, R. Z. (2011). The Impact of Locus of Control and Religiosity on Auditing Students' Ethical Reasoning. Culture \& Religion Review Journal, 2011(3), 46-68.

Enundu, T. O. (2018). Ethics and Business in Higher Education. Globethics.net education ethics, No. 2, pp. 61-73 Eweje, G. and Brunton, M. (2010). Ethics Perception of Business Students in a New Zealand University: Do Gender, Age, and Work Experience Matter? A European Review, Vol.19 No. 1

Ferrell, O., Fraedrich, J., and Ferrell, L. (2015). Business ethics: Ethics decision making and cases $\quad\left(10^{\text {th }} \quad\right.$ Ed.). Stamford, CT: CengAge Learning.

Fouere, M. (2018). A democratic purge? Financial scandals and political turmoil in Tanzania 2008.halshs-01759372, from https://halshs.archives-ouvertes.fr/halshs-01759372

Gahir, B. (2007). An Evaluation of Business Ethics Training through DIT and Content Analysis. E-Leader, Prague, from: https://www.g-casa.com/PDF/Gahir.pdf cited on $18^{\text {th }}$ January 2018

Gaur, A.S. \& Gaur, S.S. (2009). Statistical Methods for Practice and Research: A Guide to Data Analysis Using SPSS $\left(2^{\text {nd }} E d\right)$. California, SAGE Publications Inc. Retrieved: October, 09. 2018 from: www.sAgepublications.com

Glenn, J. R. (1992). Can a Business and Society Course Affect the Ethical Judgment of Future ManAgers? Journal of Business Ethics 11, 217-223

Guererro, H. (2010). Excel Data Analysis: Modelling and Simulation. Springer Heidelberg Dordrecht London New York, DOI 10.1007/978-3-642-108 35-8

Hunt, S. D. and Vitell, S. (1986). A General Theory of Marketing Ethics. Journal of Macro-marketing 6, 5-16 
Ike, O. \& Onyia, C. (2018). Ethics in Higher Education Foundation for Sustainable Development.Globethics.net education ethics, No. 2

Jazani, N., \& Ayoobzadeh, M. (2012). The Impact of Ethics Training Course on Ethical Behaviours of Management Students. International Business Research, 5(11), 162- 168. Retrieved from ProQuest. (1325013780)

Jones, G., Cannilla, L., and Slepian, J. (2015). Perception of Moral Wrongfulness of Unethical Workplace Behaviour: Gender and Cultural Differences. Journal of Comprehensiveness Studies, Vol. 23 (4)

Jones, J., Massey, D. W., \& Thome, L. (2003). Auditors' Ethical Reasoning: Insights from Past Research and Implications for The Niture. Joumal of Accounting Literature, 22, 45-103.

Jorge, M. L. and Peña, F. (2014). Determinants of Corporate Social Responsibility and Business Ethics Instruction in Spanish Universities. Business Ethics: A European Review, DOI: 10:1111/beer.12041

Khalizani, S., Omar, A., and Khalisanni, K. (2011). Graduate Students' Perception on Business Ethics and Capitalism: A Study in Malaysian Universities. International Journal of Instruction Administration and Policy Studies, Vol.3 (6), 85-93

Kidwell, L.A., Fisher, D. G., Braun, R. L., and Swanson, D. L (2013). Developing Learning Objectives for Accounting Ethics Using Bloom's Taxonomy. Accounting Instruction: An international Journal, Vol. 22, No. 1, pp. 44-65

Klein, J. (1965). A Commentary on Plato's Meno. Chapel Hill: University of North Carolina Press Klugman, C., and Stump, B. (2006). The Effect of Ethics Training upon Individual Choice. Journal of Further and Higher Instruction, vol.30, Iss.2, DOI: org/10.1080/03098770600617703

Kohlberg, L. (1984). StAge and Sequence: The Cognitive-Developmental Approach to Socialization. Chicago, IL: Rand McNally.

Lau, C. (2010). A Step Forward: Ethics Instruction Matters. Journal of Business Ethics. 92:565-584. DOI: $10.1007 / \mathrm{s} 10551-009-0173-2$

Lind, G. (2008). The meaning and measurements of moral judgement competence. Contemporary Philosophical and Psychological Perspectives on Moral Development and Education, pp.185-220

Mack, J. M. (2010). Impact of Formal Instruction Factors on Moral Reasoning: A comparative Study of Accounting Versus Non Accounting Majors (Order No. 3432401, Walden University). ProQuest Dissertations and Theses, 125. Retrieved from ProQuest. (Accession No 821244643)

Mawa, M. and Adams, J. (2012). East Africa. Global Survey of Business Ethics in Training, and Teaching, No.5, pp. 181-199

May, D., Luth, M., \& Schwoerer, C. (2014). The Impact of Business Ethics Instruction on Moral Efficacy, Moral Meaningfulness, and Moral CourAge: A Quasi-Experimental Study. Journal of Business Ethics, 124(1), 67-80. doi:10.1007/s10551-013-1860-6

McNeel, S. P. (199). College teaching and student moral development. In J. R. Rest \& D. Narvaez (Eds.), Moral development in the professions, (pp. 27-50). Hillsdale, NJ: Lawrence Erlbaum Associates, Inc.

Micewski, E., and Troy, C. (2007). Business Ethics; Deontological Revisited. Journal of Business Ethics, Vol.72, No.1, $17-25$

Murphy, P. (2014). Teaching Applied Ethics to a Righteous Mind. Journal of Moral Instruction, 43(4), 413-428. doi:10.1080/03057240.2014.963036

Nather, F. (2013). Exploring the Impact of Formal Instruction on the Moral Reasoning Abilities of College Students. College Student Journal, 47, 470-477.

Nguyen, L.D., Ermasova, N., and Ermaso, S. (2016). Business Ethics Perception of Russian Working Adults: Do Age, Gender, Instruction, and Various Working Experiences Make A Difference? SAM Advanced ManAgement Journal-Winter

Nwizu, S. C. (2018). Ethics, Values, and Higher Education: Policy and Curricula Reform. Globethics.net education ethics, No. 2, pp. 43-58

Prehn, K., Korczykowski, M., Rao, H., Fang, Z., Detre, J. A., \& Robertson, D. C. (2015). Neural Correlates of PostConventional Moral Reasoning: A Voxel-Based Morphometry Study. Plos ONE, 10(6), 1-12. doi:10.1371/journal.pone.0122914

Queensberry, L. G., Phillips, J., Woodbourne, P., and Yang, C. (2012). Ethics Assessment in a General Instruction Programme. Assessment and Evaluation in Higher Instruction, 37(2), 193-213.

Doi:10.1080/02602938.2010.515017

Rest, J. (1986). Moral developments: Advances in Research and Theory. New York: Praeger.

Ritter, B.A. (2006). 'Can business Ethics be Trained? A Study of the Ethics Decision-Making Process in Business Students.' Journal of Business Ethics, 68:2, 153-164

Rodriguez, C. (2017). A Quantitative Examination of the Relationship of Work Experience to Attitudes of Business Ethics in Graduate Students. Journal of Leadership, Accountability, and Ethics, vol. 14(3) 
Rossouw, D., and Stuckelberger, C. (2012). Global Survey of Business Ethics in Training, Teaching, and Research. globalethics.net. from http://www.globethics.net/

Saat, M., Porter, S., \& Woodbine, G. (2012). A longitudinal Study of Accounting Students' Ethical Judgement Making Ability. Accounting Instruction, 21(3), 215-229. doi:10.1080/09639284.2011.562012

Singh, A. K. and Mishra, N.K. (2018). Ethical theory and business: A study based on Utilitarianism and Kantianism. International Journal of Humanities and Social Development Research, Vol. 2, No. 1

Singh, D., and Stuckelberger, C. (2017). Ethics in Higher Institution, Values-Driven Leaders of the Future. Globalethics.net Instruction Ethics No.1. From www.globalethics.net/publications

Smyth, L., Davis, J., and Kroncke, C. (2009). Students Perceptions of Business Ethics: Using Cheating as a Surrogate for Business Situations. Journal of Instruction for Business Instruction, March/April

Stachowicz-Stanusch, A. (2011). The Impact of Business Instruction on Students' Moral Competency: An Exploratory Study from Poland. Vision (09722629), 15(2), 163-176. doi:10.1177/097226291101500207

Valentine, S., \& Bateman, C. (2011). The Impact of Ethical Ideologies, Moral Intensity, And Social Context on Sales-Based Ethical Reasoning. Journal of Business Ethics, 102(1), 155-168. doi:10.1007/s10551-011-0807-z

Velasquez, M. (2012). Business Ethics Concepts and Cases. New Jersey, Pearson Instruction Inc.

Waples, E., Antes, A., Murphy, S., and Munford, M. (2009). A Meta-Analytic Investigation of Business Ethics Instruction. Journal of Business Ethics, 87: 133-151. DOI 10.1007/s10551-008-9875-0

Warren, D., Gaspar, J., and Laufer, W. (2014). Is Formal Ethics Training Merely Cosmetic? A Study of Ethics Training and Ethics Organisational Culture. Business Ethics Quarterly, DOI: 10.5840/beq2014233

Weber, J. and Glyptis, S. M. (2000). Measuring the Impact of a Business Ethics Course and Community Service Experience on Students' Values And Opinions. Teaching Business Ethics, 4(4), 341-358

Weeks, W.A., Moore, C.W., McKinney, J.A. and Longenecker, J.G. (1999). The Effects of Gender and Career StAge on Ethical Judgement. Journal of Business Ethics, 20:4, 301-313

Yamen, T. (1967). Statistics: An Introduction Analysis, $2^{\text {nd }}$ Ed. New York, Harper and Row Publishers

Yazici, S., \& Siniksaran, E. (2012). Worklife matters: on the comparison of the attitudes of students and employees towards business ethics. I.U. Siyasal Bilgiler Fakultesi Dergisi, 46, 61-74 